\title{
Corporate governance and earnings management in Vietnamese listed firms: A pitch
}

\author{
Quynh Nguyen ${ }^{\mathrm{a}, 1}$ \\ ${ }^{a}$ University of Wollongong, Australia
}

\begin{abstract}
This pitching research letter (PRL) applies the pitching research framework developed by Faff $(2015,2019)$ to refine a research idea on corporate governance and earnings management. The PRL introduces the pitcher and then presents details of her application of the framework. This is followed by commentary on the pitch, along with the pitcher's personal reflections regarding the framework. These personal reflections identify how the pitcher progresses in terms of research questioning and conclude with recommendations for further research.
\end{abstract}

Keywords: Pitching research, corporate governance, earnings management, Vietnam.

\section{JEL codes: G34, M41}

\section{Introduction}

I commenced a $\mathrm{PhD}$ in Finance in July 2016 at the University of Wollongong. My field of research is corporate finance, in particular, corporate governance and its impact on different firm outcomes. My research interest springs from the period when I studied a Master's Degree at the University of Birmingham in the UK. I had the opportunity to take the subject "Corporate governance issues in fund management" with Professor Christine Mallin, who is one of the leaders in the field. At that time, she was a Professor of Corporate Governance and Finance and the

${ }^{1}$ Corresponding author: School of Accounting, Economics, and Finance, University of Wollongong Northfields Ave, Wollongong NSW 2522, Australia, e-mail address qxnguyen@uow.edu.au 
Director of the Centre for Corporate Governance Research at the University of Birmingham. Her expert knowledge in the field inspired me to study more widely in the area of corporate governance.

In June 2018, I first applied the pitching research template professionally to one of my thesis chapters, "Corporate governance and its impact on the risk of financial distress in Vietnam". I submitted the pitch to the AFAANZ Doctoral Symposium 2018 Pitching Competition and became a finalist in the finance group. During my preparation for the pitch, I discovered that reorganizing the research idea and converting it into a succinct and clear version to allow for greater communication with time-poor experts was demanding. This discovery prompted me to register for the Research Process Course (RBUS6914) at the University of Queensland in order to learn directly from the "pitch doctor" - Professor Robert Faff.

This pitch research letter applies the latest two-page pitching template introduced and developed by Faff $(2015,2019)$ for a research idea on corporate governance and earnings management. This is a "real" pitch as this research project is one of my $\mathrm{PhD}$ thesis chapters. The preliminary draft was presented on October 19th, 2019 at the University of Queensland during the Research Process Course led by Professor Faff. The personal pitch was one of the assessment tasks that students undertook in the RBUS6914 course after reverse engineering two pitches based on key and seminal papers related to students' research topics. Students presented reasons for their choice of papers and the key content of them, after which, constructive feedback from Professor Faff was delivered. The reverse engineering pitch exercises conducted at the beginning were valuable as they served to increase students' awareness of relevant and recent literature and helped them in terms of becoming more familiar with the template and its structure.

This PRL is structured as follows: Section 2 provides commentary on the pitch. Section 3 contains personal reflections on the pitch exercise. Section 4, the final section, delivers concluding remarks.

\section{Brief commentary on the pitch}

Table 1 demonstrates a completed pitch on the topic of corporate governance and earnings management (item $A$ ). A basic research question (item $B$ ) is introduced to identify the impact of corporate governance on earnings management. The proposed study is based on three key papers (item C) by Klein (2002), Lel (2019), and Wang and Yung (2011). These papers were chosen based on the suggestion in Faff (2019), namely, to select papers written by "gurus" published recently in top-tier journals.

The seminal paper by Klein (2002) was published in the Journal of Accounting and Economics (ABDC A* ranked) and was cited approximately five thousand times. 
The author is a Professor of Accounting at New York University and is well-known for her corporate governance research. Her paper examines whether a firm's audit committee and board characteristics affect earnings management. The study employs a sample of 692 non-financial firm-years listed on the S\&P 500 in 1992 and 1993 and suggests that boards structured to be more independent of the CEO are more effective in monitoring the corporate financial accounting process. In my study, I also test whether firms that comply with corporate governance regulations can reduce earnings management. However, Vietnam has a unique institutional setting, characterized by high ownership concentration, high government intervention, and generally weak investor protection as well as a hybrid corporate governance system where firms have a Supervisory Board, not an Audit committee. Therefore, existing studies that examine the relationship between corporate governance and earnings management outside Vietnam, where external corporate governance mechanisms are well-developed to protect their stakeholders, may not be generalizable to Vietnam or to other emerging countries similar to Vietnam. Taking into account the contrasting institutional settings in Vietnam, I apply a self-constructed index measurable in Vietnam to explore the role of internal corporate governance mechanisms in constraining earnings management.

The second key paper by Lel (2019) was published in the Journal of International Business Studies, which is ABDC A* ranked. Due to the novelty surrounding foreign institutional investors, the different types of them and their impact on earnings management in countries with different levels of investor protection, this study investigates the role of foreign institutional investors in influencing firms' incentives to manage earnings. The distinction in ownership is significant because in countries with weak investor protection, earnings management is more prevalent and foreign institutional investors become more active in the corporate governance environment than do domestic institutional investors. Given that governance mechanisms are often ineffective in these countries, the question as to whether foreign institutional investors can restrain earnings management activities in such countries is still unanswered. This study suggests that foreign institutional investors are associated with lower earnings management activities of firms. Furthermore, foreign institutional investors restrain earnings management only in countries with weak investor protection. As Vietnam has weak investor protection, my study examines whether or not foreign institutional investors play an active role in curbing earnings management and ameliorating accounting information quality.

The final key paper by Wang and Yung (2011), published in the Journal of Business Finance and Accounting (ABDC $\mathrm{A}^{*}$ ranked), examines the impact of state ownership on earnings management in China, a country which shares certain characteristics with Vietnam. In contrast to the conventional belief that state ownership is the root of corporate inefficiency, lower levels of earnings management were found to be more pronounced among state-owned enterprises than privatelyowned firms in China because of government protection of state enterprises. As 
Vietnam has widespread government ownership and a high level of intervention, it is encouraging when relating the findings of this paper to the study of the moderating effects of government ownership on the relationship between corporate governance and earnings management.

The study was motivated by three factors (Item $D$ ). Firstly, prior literature examines the role of deficient corporate governance as a major determinant of earnings management; however, it is limited to considering individual governance mechanisms, resulting in inconclusive findings. This troubles investors when choosing the relevant governance mechanisms to devise their investment strategy. Secondly, prior studies tend to explore the impacts of corporate governance in developed countries with different institutional settings; thus, it is "dangerous" to generalise the findings to the context in Vietnam. Lastly, this study was also inspired by the lack of empirical research on corporate governance and earnings management, which takes into account the moderating effect of ownership structure.

To respond to the unanswered questions, I have created a study design under the Idea, Data, and Tools sections (Item E, $F$, and $G$ ) in Table 1. As a novice researcher, I find it quite challenging when attempting to answer the following three questions: "What's new?" (Item H), "So what?" (Item I), and "What is the contribution?" (Item $J$ ). A key take-away that I have learned from the course is research should be of interest to a wide variety of stakeholders and researchers must be able to explain why it is important to know the answers to the questions addressed. Research should lead to the creation of innovative knowledge and/or the use of existing knowledge in a creative way. Furthermore, researchers should be aware of research engagement, and the impact of the enhancement of the interaction between researchers and research end-users. They must always be conscious of the mutually beneficial exchange of knowledge and resources as well as the substantial contribution made to the economy, society, and environment. In addition to the scholar pitching template, researchers should be encouraged to use the engagement and impact pitching template (PR4EI) developed by Faff and Kastelle (2016). 
Table 1. Completed 2-page pitch template on corporate governance and earnings management in Vietnamese listed firms

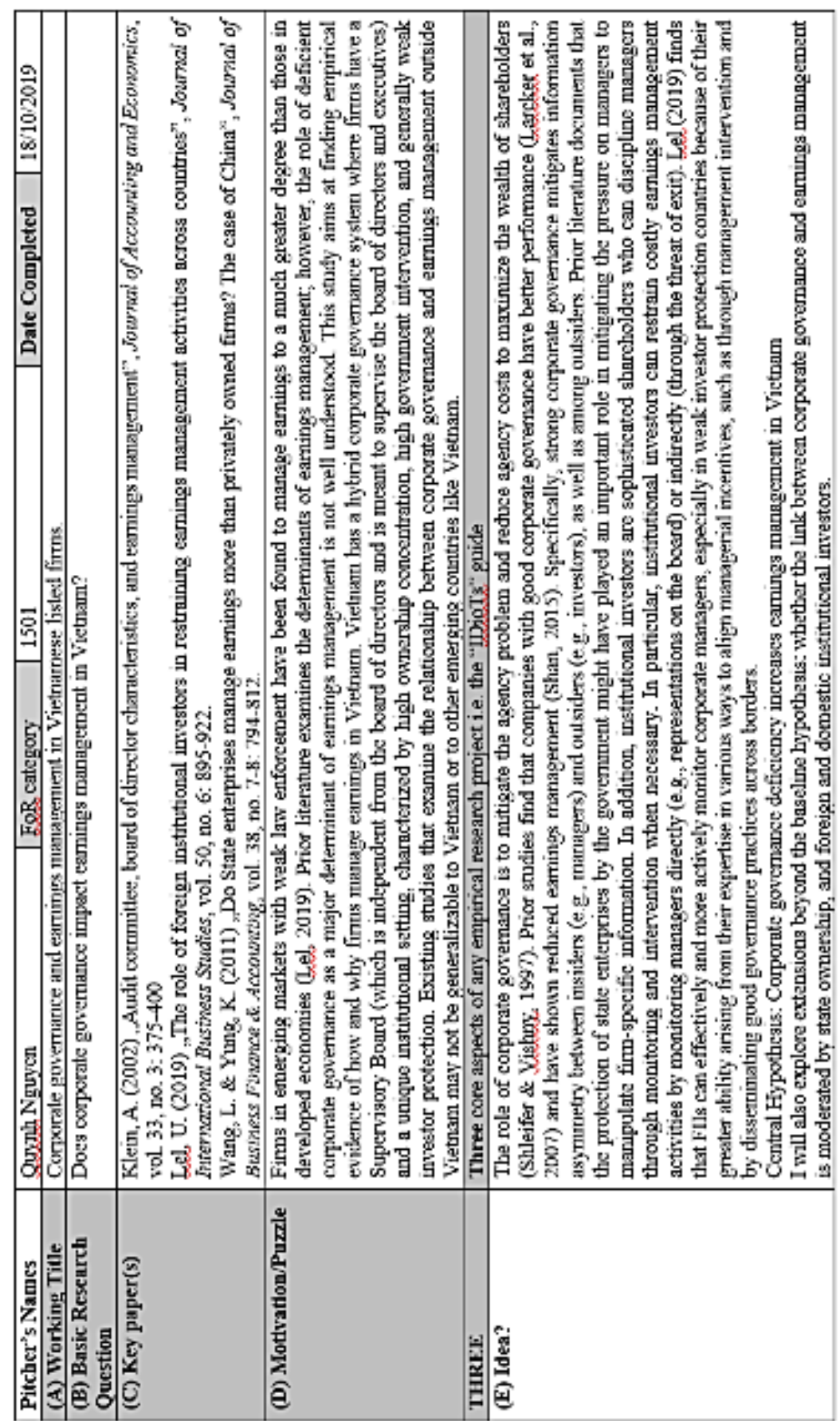

Vol. 19, No. 1 


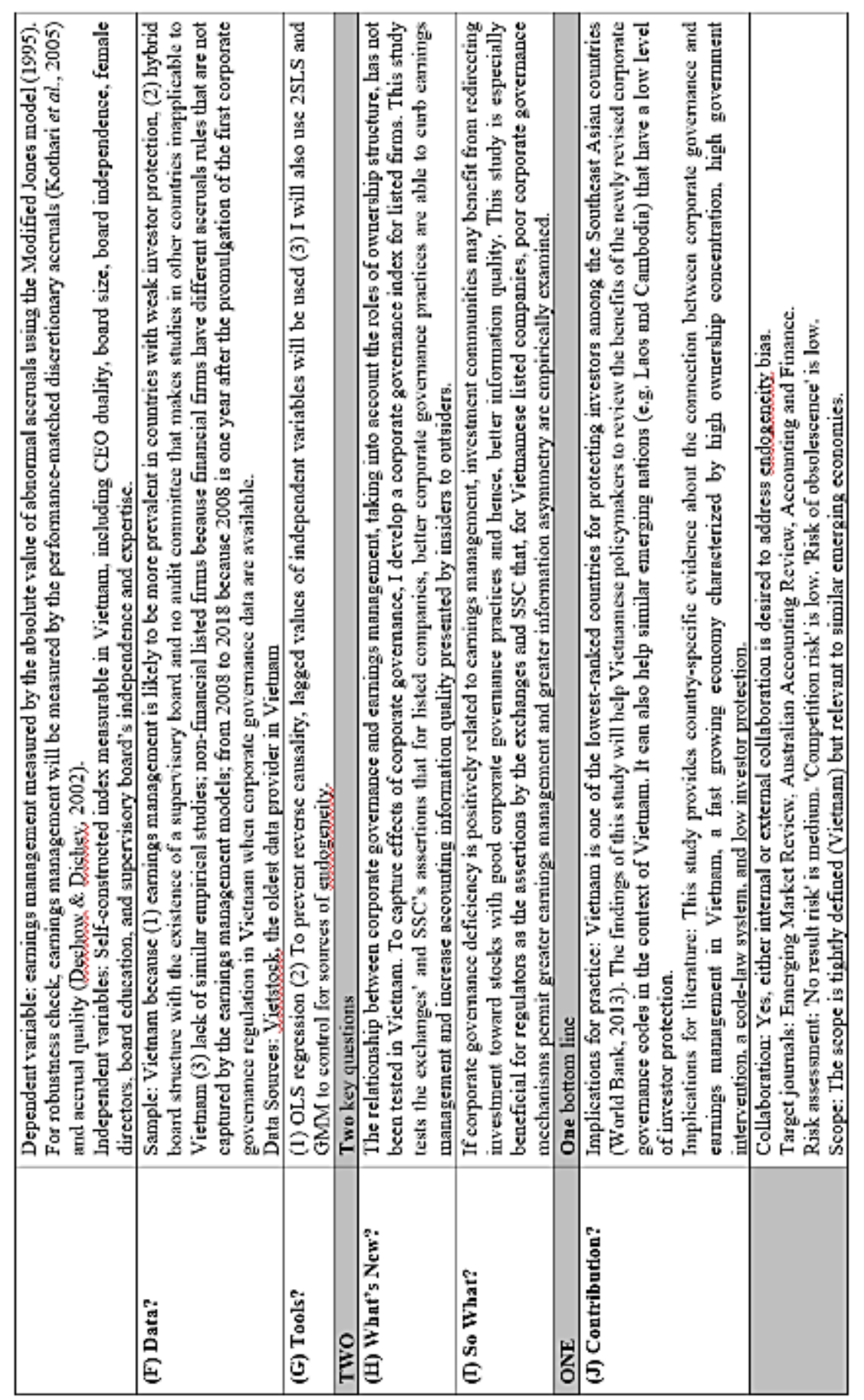




\section{Personal reflections on the pitching template}

I agree with Faff (2019) that the most demanding challenge of research is to make a sound start. Being at the embryonic stage of a research career, I find it hard to identify whether the topic that I am interested in is worthwhile and feasible to study. Especially, because of the time constraint when completing a $\mathrm{PhD}$, it is very important to avoid wasting precious time and effort on something that adds minimal value to the literature. Having adopted the pitching template for two chapters of my $\mathrm{PhD}$ thesis has helped me frame ideas, develop critical thinking, and write in a more succinct manner, which are all beneficial, especially for novice researchers. The pitching template simplifies a research plan into a "4-3-2-1" design, where "4" represents four broad ingredients about which the reader wants immediate knowledge (working title, the basic research question, the key paper(s), and motivation/puzzle), "3" indicates three critical ingredients which are the "building blocks" of a research project (idea, data, and tool), "2" embodies two important questions that help assess research novelty and significance (What's new? and So what?), and " 1 " is the number one goal for any research topic (contribution). This simplification provides more clarity during the research process and facilitates instant and valuable feedback from overloaded supervisors, resulting in potentially high-quality research publications.

Since the primary target audience of pitching research is novice researchers with only limited publication experience, applying the template is at first challenging because of the unfamiliarity with the template and lack of research experience. However, reflecting on my professional application of the pitch template in 2018 and 2019 , I now realise that the more exposure to pitching research I have and the more research experience I gain, the easier it becomes when adopting the template for my research project. Thanks to the support of Professor Faff and other students in the research process course, I have experienced a broad exposure to pitching research in different contexts and have overcome the unfamiliar challenge of using the pitch template. The pitching template has been remarkably helpful in refining and organizing my research idea and as a result, has played an important part in easing the confrontation with research uncertainties. I have started using the pitching template for my research projects as it allows me to communicate ideas to my supervisors and other experts with greater efficiency.

For beginning pitchers, I recommend choosing at least one key paper that is most relevant to their research and to reverse engineer it (see Faff et al. (2016) for example) as a warm-up exercise before doing their personal pitches. The exercise will help them familiarise themselves with the pitching template in a detailed way and prepare their thinking and reasoning for when they have to choose their research topic. The template, with its useful cues, helps pitchers focus on these signals; thus making the idea clearer for themselves. This exercise also helps them to understand how work has been done in the area and the novelty that is not understood. Reverse 
engineering other papers assists pitchers in asking the right questions and enables an organized analysis and proposition.

For a new research idea, I find that it is crucial to create a "Mickey Mouse" diagram (i.e. Venn diagram), as depicted in Figure 1. As an example, based on the relevant literature, researchers define three components or areas of research that overlap meaningfully in ways that have not been examined fully in prior studies so forming the "What's new Mickey Mouse?" diagram. This diagram is useful when attempting to assess the novelty of the research.

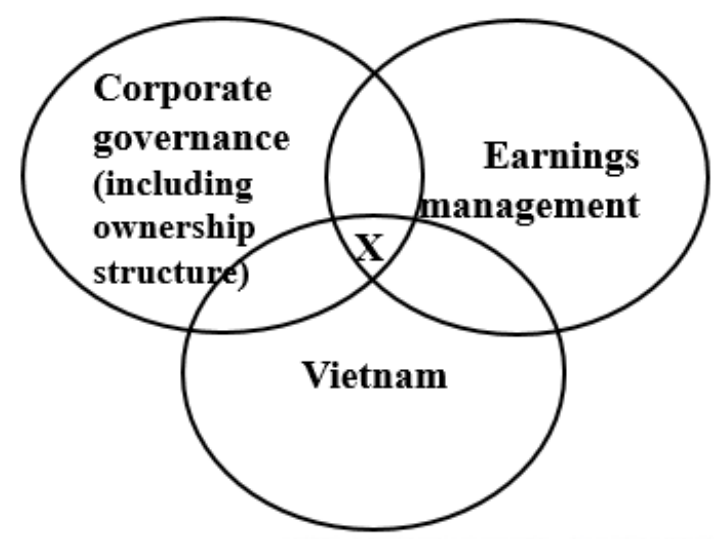

Figure 1. Mickey Mouse Venn diagram characterizing novelty of this research topic

One crucial point that was raised by Ali (2017) is the purpose of using the pitching template is to polish the research idea rather than to generate the new idea. Thus, early career researchers having a new research idea can use the template as the tool to clarify their research plan and facilitate the feedback from the experts and research mentors in a timely manner. It is essential to seek support from different sources while preparing a pitch. In particular, researchers can receive the support from "Pitching Resource Center", including (a) an e-library of worked pitching template examples i; (b) a separate listing of worked examples relevant to finance and accounting research topics; (c) the online web portal "PitchMyResearch.com" and website pitchingresearch.com; (d) the SSRN "pitching" papers; (e) doctoral symposia and coursework applications of the pitching research ${ }^{\circledR}$ framework; (f) research grant application of the pitching research ${ }^{\circledR}$ framework; (g) YouTube video resources; and other sources of support ${ }^{\mathrm{ii}}$.

\section{Conclusion}

This PRL applies the pitching template introduced by Faff $(2015,2019)$ to a proposed research idea on corporate governance and earnings management. It was initially developed for presentation in the research process course at the University 
of Queensland with the purpose of receiving constructive feedback from Professor Faff and fellow PhD students. This PRL reveals my reflections on using the twopage template for a concise delivery of the research idea to my supervisors and other experts in the field. The process of applying the pitch template, at first, seems to be time-consuming and challenging but it is worthwhile in terms of being forced to think critically and having to reorganize research ideas systematically. Given the impressive benefits of applying the pitch template, I strongly encourage other researchers to use it as a tool to refine research ideas and as assistance in the navigation of their research projects.

\section{Acknowledgements}

This PRL has been prepared for one chapter of the author's doctoral thesis at the University of Wollongong. The author is grateful to her two supervisors David Johnstone and Maria Kim, and also Robert Faff and Searat Ali for their helpful comments on the proposed research project. The author would like to express a sincere thank you to Ross Corby for his diligent proofreading of this paper. The author thanks AFAANZ for providing the Ray Ball AFDEN Travel Scholarship. The author is responsible for any remaining errors.

\section{References}

Ali, S. (2017) "Women in the boardroom and their impact on default risk: a pitch", Accounting Research Journal, vol. 30, no. 2: 137-146

Dechow, P. \& Dichev, I. (2002) „The Quality of Accruals and Earnings: The Role of Accrual Estimation Errors", The Accounting Review, vol. 77: 35-59

Faff, R.W. (2015) "A simple template for pitching research", Accounting \& Finance, vol. 55 , no. 2 : 311-336

Faff, R.W. (2017) "Pitching Research ${ }^{\circledR}$ A Comprehensive Resource Center Supplement", Available at SSRN: https://ssrn.com/abstract=3018939

Faff, R.W. (2019) „Pitching Research®”, Available at SSRN: http://ssrn.com/abstract=2462059 or http://dx.doi.org/10.2139/ssrn.2462 059

Faff, R.W., Godfrey, K., \& Teng, J. (2016) "Pitching research evolution: An illustrative example on the topic of 'innovation and financial dependence"', Available at SSRN: https://papers.ssrn.com/sol3/papers2.cfm?abstract_ id $=2776959$

Faff, R.W. \& Kastelle, T. (2016) "Pitching research for engagement and impact", Available at: https://papers.ssrn.com/sol3/papers.cfm?abstract?id=2813096

Klein, A. (2002) "Audit committee, board of director characteristics, and earnings management", Journal of Accounting and Economics, vol. 33, no. 3: 375-400 
Kothari, S.P., Leone, A., \& Wasley, C.E. (2005) "Performance matched discretionary accrual measures", Journal of Accounting and Economics, vol. 39, no.1: 163-197

Larcker, D.F., Richardson, S.A., \& Tuna I. (2007) "Corporate Governance, Accounting Outcomes, and Organizational Performance", The Accounting Review, vol. 82, no. 4: 963-1008

Lel, U. (2019) "The role of foreign institutional investors in restraining earnings management activities across countries", Journal of International Business Studies, vol. 50, no. 6: 895-922.

Shan, Y.G. (2015) "Value relevance, earnings management and corporate governance in China", Emerging Markets Review, vol. 23(C): 186-207.

Shleifer, A. \& Vishny, R.W. (1997) "A Survey of Corporate Governance", The Journal of Finance, vol. 52: 737-783

Wang, L. \& Yung, K. (2011) "Do State Enterprises Manage Earnings More than Privately Owned Firms? The Case of China", Journal of Business Finance \& Accounting, vol. 38, no. 7-8: 794-812

i The e-library can be accessed at http://www.business.uq.edu.au/supplementary-materialpitching-research

ii Researchers are strongly encouraged to access $\operatorname{Faff}(2015,2017,2019)$ to learn his extensive resource pool. 